\title{
The Vivid Alphabet: Media and Mass Literacy in the Early Modern Military State
}

\section{Thomas Götselius}

\begin{abstract}
This article explores the connections between literacy, media technology and power in early modern Northern Europe. Designed as a genealogy of mass literacy, it suggests that the extremely successful literacy campaign in the kingdom of Sweden (dating back to 1686) was based upon a new kind of writing, a reshaped alphabetic technology, coterminous with a new technology of power, namely discipline, which originated in the army. At the same time, it argues that militarization of society, rather than consolidation of Lutheran faith, provides the pertinent context in which the take-off of universal literacy in Northern Europe, and, consequently, in the West, must be interpreted. Thus it becomes possible to explain why mass literacy was first achieved in Sweden, a state of imperial ambition were military needs and military organization permeated every aspect of society.
\end{abstract}

\section{RÉSUMÉ}

Cet article explore les liens entre l'alphabétisme, les techniques médiatiques et le pouvoir en Europe du Nord au début de l'époque moderne. Conçu comme une généalogie de l'alphabétisation de masse, ce travail expose comment dans le royaume de Suède (à compter de 1686) l'énorme succès d'une campagne en faveur de l'alphabétisation s'appuyait sur une nouvelle forme d'écriture et une réforme de l'alphabet tout en s'associant à une nouvelle technique de pouvoir, à savoir la discipline, notamment celle de l'armée. De plus, cet article montre que la militarisation de la société plutôt que de consolider la foi luthérienne crée un contexte propice à l'émergence de l'alphabétisation universelle tant en Europe du Nord qu'à l'Ouest. Ainsi, il devient possible d'expliquer pourquoi l'alphabétisation de masse démarre en premier lieu en Suède, un État aux visées impérialistes au cœur duquel les besoins militaires et l'organisation militaire imprégnaient tous les aspects de la société.

In the beginning, peoples and letters were separate. In 1686, however, this divide came to an end as authorities in the kingdom of Sweden made reading instruction mandatory. Officially a part of religious education, this highly successful national literacy campaign provided the first ever example of the alphabetization of an entire people or population. ${ }^{1}$ The campaign, which was launched as the kingdom (at that time consisting of all 
of modern Sweden, Finland, Estonia, and parts of Northern Germany) stood at the height of its imperial ambition, is renowned not only because of its effectivness, but also because of the way it was carried out. Long before the heyday of compulsory schooling, the Swedish clergy made Lutheran home learning serve as a kind of reading instruction. What the Protestants in the German lands had been unable to achieve for 150 years, their Swedish counterparts accomplished in little more than a generation. ${ }^{2}$

The remarkable results were due, in part, to access to new and powerful tools of alphabetization; however, studies on the early history of literacy in Sweden have so far largely avoided detailed treatment of alphabetic technology and literacy practice. ${ }^{3}$ While the role of home learning has been underscored by a leading scholar in the field, Egil Johansson, the main achievement of his research remains his analysis of the campaign using Swedish church books. Extracting statistical evidence out of catechetic records, Johansson proved that the demands of the Church Law of 1686, where skills in reading (not writing) were mandated, was followed by a campaign in Finland and metropolitan Sweden. In explaining the success of this campaign, Johansson pointed not to technology or practices, but to the religious context. The spread of letters was a means to inculcate "correct" religious ideas and thus a way to cosolidate the religious change of the Reformation. Taking the religious character of the campaign at face value, Johansson, in fact, came to challenge the once postulated linkage between literacy and modernisation. The case of Sweden, where neither schools nor industrialisation were dominant developmental factors, indicates that literacy need not be tied to modernisation. ${ }^{4}$

Although this conclusion may seem theoretically sound, the historical analysis leading to it can be questioned in several ways. First, the spread of letters in Sweden obviously took place in a religious setting, but the motivations underlying the campaign have not been thoroughly examined. ${ }^{5}$ After all, the campaign was launched long after the Lutheran reformation had been consolidated and a considerable time after Sweden's participation in the Thirty Years' War. Second, Johansson's claim that the increasing requirements for knowledge in seventeenth-century Protestantism triggered alphabetization is problematic. ${ }^{6}$ Is it not just as likely that the slow but apparent improvement in lay literacy in the wake of the Reformation lured church officials gradually to increase the requirements for knowledge? Third, and most important, when conceived of as a strictly religious affair, the alphabetization of Sweden is inevitably read back into history and appears primarily as the much belated realization of the ideas of the Lutheran Reformation. Johansson and his followers thus fail to account for full-scale mass alphabetization as something historically new. Instead, they consider it as extraneous to modernization, and this may, in turn, explain why they fail to recognise the innovative character of the mechanisms governing religious language instruction and alphabetization in seventeenth-century Sweden.

In this essay, I will read the campaign the other way around, as a part of "modern" history, as a process that heralds "modern" mass literacy, and, finally, as an event that allows us to trace the very conditions of possibility for mass literacy. Of course, such an inquiry into the origins of universal literacy still has to address religious matters, though this time not as a force that explains the spread of letters, but as something that itself has to be explained or interpreted in terms of cultural practices. For this reason, I will explore 
the campaign as an apparatus of literacy; that is, as a particular configuration of techniques, media, and power governing the use of letters in a specific cultural environment. Instead of taking literacy for granted, as something self-evident and already known, I will trace how it was "fabricated in a piecemeal fashion from alien forms of knowledge;" thus the analysis of the apparatus becomes identical to a description of its genealogy. ${ }^{9}$ To be more precise, I will suggest that the extremely successful literacy campaign in Sweden was based upon the appearance of a new kind of writing, a reshaped alphabetic technology and a new form of power, namely discipline, which originated in the army. At the same time, I will argue that the militarization of society, rather than the consolidation of Lutheran faith, provides the key context for the interpretation of universal literacy in seventeenth-century Sweden.

The essay is divided into three sections, each devoted to one of the "alien forms of knowledge" that makes up the apparatus of literacy. In the first section, we will trace a new concept of writing that appeared practically at the same moment in the sixteenth century as the idea of general alphabetization. Before the Word of God was distributed across the whole of the population, it was redefined as a medium of amazing sensorial qualities, which had the power to produce sights and sounds more real than reality itself. This new multi-medium of writing soon got a material substrate in early modern alphabetic technology, as it was construed in the methods of popular alphabetization. In the second section, we will examine the formal correlations beween the medium of writing and the literacy practices that were developed in the sixteenth and seventeenth centuries by reformed pedagogics. The discussion focuses on a pleasure-promoting primer written by Johann Amos Comenius in which he introduced his "vivid alphabet." With a detailed analysis of the Swedish literacy campaign, the third section takes a closer look at the role played by the Comenius primer and its pleasure-promoting practices in Sweden. Although the primer is said to have saved children from the rod, this alphabetic technology is revealed to be a technology of power as well, one that produces performance primarily through recurrent examination. Discipline, then, is clearly the form of power deployed by the Swedish authorities, and, therefore, the apparatus of literacy - the particular configuration of media, practices, and power governing the use of letters in seventeenth-century Sweden — cannot be understood outside disciplinary society. Tracing discipline back to its roots in the army, the essay ends with an argument concerning the military origins of modern mass literacy and the disciplinary imprint that may still be uncovered in its practices.

\section{The Word of God and the medium of writing}

Literacy is fed by literature, from which it cannot be separated. The Swedish Church Law of 1686 states it to be the duty of the Swedish clergy to "diligently press Children, Farm-hands and Maid-servants to learn how to read in a Book and see with their own eyes what God bids and commands in his Holy Word." 10 In 1686, literature was the Word of God and nothing else. The idea that letters should be of general concern for the people would have struck the authorities of Sweden as strange and bizarre, just as the idea that the Word of God was of concern for everyone had struck other authorities as 
bizarre and even heretical in the beginning of the sixteenth century. The Word, in other words, is not the same thing in Protestantism as in Catholicism, just as it is not the same thing in the fifteenth century as in the sixteenth century. ${ }^{11}$ These differences are not expressed primarily in theological concepts, although they can be seen there as well, but rather in the shifting discursive practices that govern the technologies of the Word (i.e., the medium of writing). Instead of identifying the Word of God as simply the bulk of texts of bibles, catechisms, choral books, or devotional books, it is necessary to trace how writing was technically manipulated in the religious context of early modern Northern Europe to produce determined effects in a certain set of readers.

The idea that the separation between people and letters must come to an end in the name of God and his Word is very clearly a part of the Lutheran legacy. Yet the idea that every Christian must have access to the very words of the gospel predates the Reformation by one year. In fact, it coincides with the invention of the idea of the "very words" of the gospel and the appearance of the first edition of the New Testament produced by liberal philology, Desiderius Erasmus' Novum Instrumentum. Appearing in 1516, this gospel was self-consciously advertised as "the true Greek text," as opposed to the standard text of the Western church, the latin Vulgate, whose status as a - partially doubtful — translation was exposed at the same time. ${ }^{12}$ Novum Instrumentum immediately became a watershed in the public European debate on religious reform and, more importantly, a matrix for a new kind of writing that provided the technical basis for Protestantism. Articulated for the first time in the textual criticism of Erasmus, the idea of the true or original text would later be turned into a basic theological concept of Lutheranism. Erasmus owed this idea to the revolution in communication technologies of the late fifteenth century, which provoked a number of important conceptual adjustments as well. ${ }^{13}$

The impact of Erasmus' new edition of the Bible, however, was not confined to the assertion of sola scriptura or to the text itself. If Novum Instrumentum became a matrix of a new kind of writing, it was because Erasmus instructed his readers how to read his gospel and prepared them for a certain kind of reading experience. In the preface to the pious reader, called Paraclesis, Erasmus, in effect, sets out to redefine the Word of God and its reader. The cornerstone of this redefinition is the claim that the text of Novum Instrumentum reveals "the truth itself," ipsa veritas, since it is written by "Christ our author and master," autori nostro et principque Christo. ${ }^{14}$ This attribution was a novel one to say the least. Although Aquinas and other medieval theologians had talked of God as the author of the Bible, no one had yet seen Christ as an author of his own gospel or had made the idea of the author an issue central to exegesis. In this way, Erasmus' thinking reflects humanist practice and the institution of literary authorship as it had emerged with humanism in the fifteenth century. ${ }^{15}$ Before such humanist scholarprinters as Froben or Aldo Manuzio appeared in the early 1500s, no one had thought of placing the name of an individual on the first pages of a book. As traditional, divine authority was transferred to a new non-mythical type of writer, texts that had formerly circulated anonymously were suddenly ascribed to authors. "If, at the end of the Middle Ages auctores became more like men, men became more like auctores." of Jesus for God, of the Son for the Father, of mediating authority for absolute authority, 
is analogous to the process that around $1500 \mathrm{AD}$ allowed for the appearance of the demigod we now know as the author. Thus, Erasmus authorises his gospel by inserting Christ as the author in a place which hitherto had been left empty in Western discourse.

By grounding the truth of the gospel in terms of literary practice, Erasmus defined two important principles for the promulgation of the gospel. First, since Christ, more than anything else, is the author of his own literature, Christi litteras, you cannot be a Christian without also being a reader. Thus, in order to profess Christianity, you have to be a reader of the gospel. Second, if the authorship of Christ guarantees that the text provides us with "truth itself," then the text does not only authorize itself, it also becomes practically self-interpretative. ${ }^{17}$ In comparison with the gospel, all other kinds of knowledge appear as obscure and dubious, and this applies even to theology, the queen of disciplines. Since theology is the knowledge of the logos of God or the interpretation of scripture, Novum instrumentum is, in effect, beyond interpretation. All that is required to understand the text is "a pious and open mind" and "a pure and simple faith," since the letters and literature of Christ inscribe the "truth itself" within readers. ${ }^{18}$

At this point, it becomes clear why Erasmus must be held responsible for the historically unique idea of universal alphabetization. Of course, a knowledge of letters has always been central to Christianity, but, as in all traditional societies, Western medieval society restricted literacy to the religious caste, on the condition that it would work diligently for the spiritual well-being of the whole of the community. However, according to the definitions put forward in Paraclesis, this restrictive practice is a fraud that must come to an end. If truth itself is synonymous with the very letters of the gospel, reading becomes not only the ontologically privileged way of apprehending truth, but the only way to do so. Hence, Erasmus differs "compassionately" from "those who do not wish to have the Holy Scriptures translated into the vernacular." Christ did not want to hide his teaching; he wanted to disseminate it. ${ }^{19}$ Thus, Christ emerges as equally accessible to women, to the poor, to the uneducated, and even to the Turks or Saracens. In what has become the locus classicus of the dream of universal alphabetization, Erasmus longs to hear the farmer singing the words of the gospels at his plough and the weaver humming them to the movement of his shuttle. ${ }^{20}$

Yet no dream has in itself brought about the fall of any clerical monopoly of letters. In order to pave the way for lay literacy, Erasmus ensured that powerful effects, in terms of vivid sights and sounds, would be produced within readers of the literature of Christ. To understand these effects, we have to take a closer look at the implications of Erasmus' identification of Christ as author. The basis of the new construction of authorship around $1500 \mathrm{AD}$ was the assumption that the author guaranteed the supposed unity and intelligibility of the work. ${ }^{21}$ As a consequence of this profound identity of work with author, it became possible, and even desirable, to read texts in order to evoke the genius of the author. In fact, to read came to involve the very visualization of the picture of the author in the mind of the reader. To demonstrate this principle, we have to look no further than to Erasmus himself. In a commentary on Hans Holbein's famous portrait of Erasmus, the author's secretary, Gilbert Cousin, says that the picture may be striking in its likeness to its model, yet Holbein's talented hand cannot reproduce the voice of the author, something which is the provenance only of writing: 
For see how on occasion the portrait of his intelligence appears to you in his books, living and without artifice, more clearly than in a mirror. And this form of the man's appearance deserves far greater attention; that which the painter has represented is only the enclosure of the mind. Consider therefore that you see a portrait of Erasmus each time that you read the products of his genius. ${ }^{22}$

When presence is the desired effect, the medium of the image cedes ground to the medium of writing. Yet the fact that Cousin's final homage to writing is expressed in terms of another medium ("portrait") reveals that the medium of writing is constituted not by itself, but rather by the supplementary medium of the image. More important, though, is the fact that Cousin's passage testifies to a new practice of reading that is coterminous with the institution of authorship. To read is now simply to make the author present. In Paraclesis, where Christ is introduced as author, the same principle is brought to bear upon the gospel. As "our author" has promised "to stay with us until the end of time, he keeps this promise first and foremost through his writings, within which he now lives, breaths, speaks to us, almost more effectively, I must say, than when he dwelt among men." And Erasmus adds: "The Jews heard him and saw him far less than you will hear him and see him in the writings of the gospel, just see to that you are all eyes and ears, so that you are able to see him and hear him." 23

Thus, the writing (litteris) of the author has the power to make the absent person fully present. Through the metaphors of "life," "breath," and "speech," writing is equated to the physical presence of Christ, and the Novum instrumentum is defined as identical to the living body of the author: "These [writings] bring you the living image of his holy mind and the speaking, healing, dying, rising Christ himself, and thus they render him so fully present that you would see less if you gazed upon him with your very eyes." ${ }^{24}$ This final passage clearly states the function served by reading practice: namely, to produce a presence that creates a breathtaking experience. "If we wish to awaken our dull and listless soul through reading, where, I ask, do you find a flame as vivid and effective [as in the gospel]?" 25 Just as Cousin asserted that the picture of Erasmus appears more vividly in his writing than in a mirror, Erasmus argues that Christ the author appears more vividly in his writings than in real life. Thus, Paraclesis establishes the literature of Christ as phantasmatic.

In the context of Western media history, this moment definitively widened the scope of writing, particularly at the expense of the image. In late antiquity, pictures had been used by the church to solve the difficulty of disseminating Christianity among the newly or still-to-be converted peoples of the former Roman empire. According to a letter of Pope Gregory the Great dated $600 \mathrm{CE}$, images are writing for those who cannot read: "For that which is made available through scripture to those who read is presented to the ignorant through pictures, because in pictures they see what they ought to follow; they read in pictures who have no knowledge of letters." ${ }^{26}$ In other words, the image has the ability to envoke presence just like the written word.

Originally designed to spread the gospel to the illiterate, Gregory's defense of images not only came to secure a place for visual experience in Christianity, it also helped secure the clergy's monopoly of letters. As long as pictures were equal to 
writing, lay literacy was dispensable. ${ }^{27}$ Hence, Erasmus' claim that only writing can make "truth itself" fully present overturns the age-old Christian media hierarchy. Texts are pictures for those who are able to read, goes the literally revolutionary conclusion of Paraclesis, whereby the actual viewing of pictures of Christ in church cedes ground to the phantasmatic images that are produced within readers through the reading of the true and original gospel. In a single stroke, a millennium of church art and biblia pauperum was rendered irrelevant.

Of course, in reality things were a bit more complicated. After all, images formed only a part of the multi-medial medieval Christian society that such a book as the Novum Instrumentum was confronting. Through masses, images, plays, the rites of the religious holidays, and music, the church appealed to all the senses in order to captivate those who were unable to read. It is in this context that the phantasmatic character of the literature of Christ finally must be interpreted. What the church offered through manifold transparent media, pious humanists could only transmit through alphabetic signifiers. In order to compete, writing had to be reinvented and made superior, or at least equal, to other media in terms of its sensorial effects and bodily attraction. Hence, in the place of the old multimedia play of visual, auditory, and olfactory signs in Christian ritual, Erasmus launched a kind of writing that, although explicitly stated as a supplement to direct sensorial experience, was said to be even better than the real thing.

If Erasmus' invention seems, at this point, strangely familiar, it is not because we have transposed a modern media problematic to an early modern age, but rather because our world of media, wherein each medium promises to reform its predecessors by offering a more immediate or authentic experience, has its point of departure in the age of Erasmus. ${ }^{28}$ After all, the invention of print is still the major media revolution that produced the pattern to which later revolutions still adhere. Like other theoretizations of media since the Renaissance, Erasmus' writing oscillates between transparency and opacity, between immediacy and hypermediacy. On the one hand, the strong emphasis on the Word's presence tends to dissolve its medial facticity: the presence of Christ in visual, auditory, and bodily terms requires the sudden forgetting of language as such. On the other hand, the literature of Christ is almost conceived of as a hypermedium, as a medium whose content is defined in terms of other media (i.e., image, voice, body, etc.). As in the case of Cousin, writing in Paraclesis is constituted by the media it is designed to surpass. Furthermore, the simple fact that very few knew Greek ensured that mere letters or were never forgotten. Although Erasmus promoted lay reading through translation to the vernacular, his profound claim that the Novum Instrumentum presented "truth itself" rested on the premise that the letters of the Greek text offered direct access to the original presence of the author. ${ }^{29}$ Leaving aside the paradoxes that this point raises, Erasmus' claim to offer a more immediate or authentic experience inevitably lead his readers to become aware of the new medium of writing as a medium. ${ }^{30}$

Far from being to its disadvantage, however, the acknowledgment of Erasmus' medium as a medium turned out to be a part of its success in sixteenth- and seventeenth-century Northern Europe. As the telling formula of sola scriptura indicates, the medium as such formed a part of the message of Protestantism. Accordingly, many attempts have been made to explain the success of the Word or the Reformation in 
terms of a media revolution. ${ }^{31}$ What media historians and social historians of the Reformation alike tend to neglect, however, is that books do not produce effects by themselves just because they happen to appear in print. ${ }^{32}$ Before the Word could have a career outside the clergy, there must have been rules that confirmed its cultural significance, and there must have been rules that governed its uses and that determined its effects.

In other words, at some point the function of the medium had to be instituted. This is precisely why Erasmus' preface deserves our interest, since the Paraclesis operates on this elementary level. ${ }^{33}$ Like so many avant-garde treatises throughout history, the preface has a foundational character. ${ }^{34}$ Inventing for the first time ever a kind of writing that was to be read by virtually everyone, Erasmus made the definitions of the true and original text contain a positive program for reading that prescribed the experience of its future readers. In terms of media competition, the startling phantasmatic experience that was provoked by this program was a means to secure the universal dissemination of the Word.

In order to experience anything at all, however, "everyone" first had to learn how to decode the simple alphabetic letters that still made up the Word. The question remains how the redefined medium of writing was connected to individuals in the first place. Thus, we must examine how the Word was instituted on the most elementary level. What measures were taken to secure the spread of the Word? How was the alphabetization that was triggered by the invention of the Word, in fact, designed? In what way, if at all, did the redefinition affect literacy practice?

\section{Alphabetic technology and reform pedagogy}

In the beginning was not the Word, but the ABC book. Because "no one can be sanctified without the written word [litterae],"35 a new type of primer that paved the way for universal sanctification and that entrusted each individual with its own alphabetization appeared in the first part of the sixteenth century. ${ }^{36}$ The list of such books is long and includes Jakob Griessbeutel's A Most Useful Book of Sounds, Illustrated with Figures Giving the True Sound of Each Letter and Syllable, from Which Young Men, Husbands and Wives and Other Adults, also children, Women as Well as Men, Can Easily Learn to Read in as Little as 24 Hours; Valentin Ickelsamer's A Correct and Quick Way to Learn Reading and A German Grammar from Which Every Man Can Teach Himself to Read...; Peter Jordan's The Layman's School: An Easy and quick Method for Learning to Write and Read. With a Technique for Instructing the Hard-of-Learning and Dull-Witted without the Use of Letters, but through Figures and Characters Attractive to Look at and Easy to Remember; Ortholph Fuchtssperger's, The Art of Reading...; Johann Kolross' Manual of German Orthography; and Johannes Meichssner's A short Manual for Fundamental Instruction in Spelling and Handwriting. ${ }^{37}$

The titles speak for themselves. Announcing the end of the clergy's monopoly of letters, they leave little doubt about the drive for lay reading. "Such books," writes Jordan, "are used everywhere. Each year a new title appears on the market." ${ }^{38}$ Although the motive of the drive is not clear, it is usually revealed in the prefaces of the primers. "Now that the bible has been printed in German," wrote Johann Kolross introducing 
his Manual of German Orthography in 1530, "all the artisans and housemaids, though working all day in the sweat of their brows, want to spend their evenings pondering the word of God." 39 Though certainly an exaggeration, this was obviously the belief of Kolross. "Only a few rare spirits achieve enlightenment without reading," said Ortholph Fuchtssperger, echoing Melanchthon's law of sanctification, in his Art of Reading in 1542. "Most of us depend on books for what we need to learn about our duties toward God and our fellowmen." 40 "I was moved [to write this book]," Valentin Ickelsamer explained in the preface to his German Grammar of 1534, "not only because I know that reading brings much pleasure to those who have mastered it, but also because this skill is a splendid divine gift, which we should use to honour God by reading, singing and writing." "Never before has the art of reading been so beneficial," he added, "as in our day, when each man by himself can know and judge the word of God." ${ }^{\prime 11}$ At the same time, Ickelsamer and other pedagogues recognised literacy as indispensable to the everyday life of German burghers. "Everybody nowadays wants to be adept at a skill with which one discovers, understands, and remembers everything in the world and can communicate it to others, no matter how far away they are." ${ }^{42}$ His book, he contended, could prepare anyone to be ready within a few days to read and write. He himself had taught people to read in as little as a week. In fact, he claimed it could even be done overnight. ${ }^{43}$

Such audacious declarations reveal a hidden problematic. If learning to read was as easy as these authors claimed, why the need to emphasize it so? Behind the obvious promotional interests, the claims of these authors refer to the state-of-the-art in literacy education in the sixteenth century. In 1500, learning to read went hand-in-hand with learning Latin, and this double undertaking was a difficult and time-consuming business. The methods in use in elementary education seem to have left many pupils less than fluently literate. The procedures followed were more or less the same as in medieval times or in antiquity.

According to Gerald Strauss, German schools made pupils perform according to a "synthetic system," which relied on slow, repetitious, cumulative, habit forming drills: "Moving from the simple to the complex, from parts to the whole, $\mathrm{ABC}$ learning started the pupil on letters (learned by name and sound), advanced him to syllables, then to words, eventually to sentences, from there straight to the German catechism." ${ }^{\prime 4}$ Integrated in this "synthetic system" are obviously those procedures that were later to be called the syllabic and the spelling methods. The syllabic method shows children syllables and their pronunciation and has them repeat these. According to Martin Luther, you have to "dispute crassly" and "chew before" in order to teach "analphabetic boys [to] connect syllables." ${ }^{5}$ Through much practice children learn syllables and words in the entire outline of their forms along with their pronunciation. This is a difficult procedure with obvious deficencies, as children, if they have not been fortunate enough to notice for themselves the sounds of letters, always run into trouble when they encounter syllables and words of unfamiliar composition. The spelling method proceeds from the assumption that the name of the letter is also its sound and that, therefore, it is necessary to precede the pronunciation of every syllable with spelling (naming of each letter). The syllabic method consisted in rote learning of the links between 
optical and acoustic syllabic images; the latter in rote learning of simple words, the name of letters. Spontaneous readability was excluded in both cases. ${ }^{46}$

The almost magical results promised in the titles of printed primers clearly formed an implicit denunciation of the age-old, tedious practice that was known as learning litterae.$^{47}$ If reading skills came to be associated with hard and tiresome work, the prospects for universal literacy were indeed bad. Besides, it was not likely that adults would submit themselves to the same school drills as youngsters. In order to promote reading and thus universal sanctification within the whole of the population, the authors of teach-yourself primers had to bypass the school route to literacy.

Ickelsamer, the most influential of the popular literacy pedagogues, presented, in his Ein Teutsche Grammatica, the most clear cut alternative to school alphabetization. ${ }^{48}$ Instead of spending years struggling with nonsense syllables, he suggested that students should learn the alphabet from the sound of the words of their mothertongue. "Take the name Hans," he explained, "You have four sound changes in this word, which are represented by four letters. First, you hear a strong exhaling noise, as when someone heaves a deep sigh. This is the $\mathrm{H}$, which you breathe into the vowel A. Following this there is a sound through the nose and finally you hear a sibilant like the hissing of a snake." ${ }^{29}$ The next step, Ickelsamer continued, was to imagine a picture to associate each of these sounds with a written letter. Let's say that you want to read the word Mertz (März, March). First note the four sound changes, then think of an animal or object vivdly representing each of these sounds. Draw a cow over the moo-sound $\mathrm{M}$, over the goat sound $\mathrm{E}$ put a goat, a dog over the growl R, and finally a bird over the sparrow cry TZ. According to Ickelsamer, nothing could be easier or more entertaining. ${ }^{50}$

This alternative approach to alphabetic letters represents a moment of invention in the history of alphabetization. ${ }^{51}$ Where the Western tradition since Plato had understood writing as "painting of speech," Ickelsamer conceived of writing primarily as voice analysis. Although the proposed procedure seems both natural and fast moving, no one had actually thought of starting with sounds rather than with graphic articulations before the German grammarians. Advancing what was to become the "phonetic method," Ickelsamer displayed a blueprint for the future oralization of the alphabet. However, the repressed, traditional idea of speech as painting seems to return through the back door in his procedure, though this time as real pictures of animals representing individual sounds. Instead of the age-old troublesome graphic syllabarium, Ickelsamer proposed an alphabet that was conceived of in terms of sounds and pictures (of sounds). Literally a pleasure-promoting pedagogical device, the stipulated connection of letters, sounds, and pictures was supposed to simplify and facilitate learning. If reading, according to Ickelsamer, "brings much pleasure to those who have mastered it," it was because the sights and sounds of his mooing and growling alphabet replaced the less visceral play of signifiers alone.

What the primers tried to cope with through methods like Ickelsamer's was the enormous difficulties pedagogues encountered when exhorting hard working populations, mostly consisting of farmers and country people, to take an interest in the strange business of reading. Hence, his method provides a strategy to overcome any plausible resistance to reading - a resistance in itself a reflection of the strange materiality of the 
medium and the cultural techniques governing its use - by turning an alien alphabetic technology into something familiar. This is why the immediate lifeworld of country people makes up the content of the primer. Moreover, this immediate lifeworld is not just any world. In Ickelsamer's primer the initiation to the alphabet seems to be folded back upon the initiation to language itself.

For what does the scheme of the primer secretly describe, leaving letters out of the account for a moment, if not the intimate scene where parents name the world to their children in order to teach them the elements of language? The alphabet is introduced in a way that refers the strange signs back to the child's pleasurable discovery of the world and of his or her own voice. Accordingly, Ickelsamer's method granted that the future reader would be kept not only within a familiar lifeworld, but within the lifeworld of oral speech. The artificial, angular, monotonous, black and white universe of writing was simply bypassed. For those who were alphabetized by the method of Ickelsamer, the act of reading became synonymous with caressing their own ears and eyes with sweet, familiar sounds and images. In short, it coincided with the reproduction of infantile pleasure.

Hence, Ickelsamer's reformation of the alphabet in Ein Teutsche Grammatica has obvious formal affinities with Erasmus' reformation of the Word in Novum Instrumentum. Exactly in the same way that the Word appeared to its readers as sounds and images as soon as they forgot the letters themselves, the letters of Ickelsamer's primer brought sounds and pictures to readers as they too bypassed the signs in front of them. In both cases, writing was equated with presence, not absence or lack, as is otherwise the case in the Western tradition. This structural coherence is no mere coincidence, since Ickelsamer, first and foremost, was a pedagogue of the Reformation and thus intimate with every aspect of the Word. ${ }^{52}$ Departing from the same multimedial medieval context as Erasmus, Ickelsamer took part in the redefinition of writing as the medium that encapsulated all other media by inventing a corresponding alphabetic technology in support of that very writing. Having learned to read by Ickelsamer's primer, people were programmed to experience the magnificent play of sights and sounds that awaited the readers of the Protestant gospel.

Despite this beautiful symmetrical alliance between primary practice and advanced media, Ickelsamer's invention never made its way into the institutions, where teachers opposed "method," i.e. oralization, and stuck to traditional elementary instruction throughout the sixteenth century. By the mid-seventeenth century, however, the strategy of oralization deployed by Ickelsamer was appropriated by another Protestant pedagogue, Johann Amos Comenius (Jan Amos Komensky). As a part of a new wave of reformed pedagogics, Comenius reacted against traditional instruction in general and reading instruction in particular. Hence, he promoted "method" in popular reading instruction, and at the core of his method was the relation between the primary naming of the lifeworld and the secondary acquisition of letters that was latent in Ickelsamer's sixteenth century blueprint. "We will teach the words to children," Comenius writes in Pampedia, "under the guidance of things, that is, at the same time we teach them to speak and to know." All the time teachers have to "show the thing and to ask: What is this? - One may name the thing and have it pointed out: Where is the dog? Where is the table? Where is your head?" 53 According to Comenius, this was the right way to turn the babble of infants into discourse: 
Exactly in the same way, language begins with nothing but babbling, continues by way of stammering to speech; always under the guidance of the sight of oneself and the sense of feeling of oneself. For we cannot speak of these things on the level of concepts to those who have not yet detached concepts from things and engraved them in their soul, so that they are able to perceive how its meaning is put in motion by the sound of a voice. That is why it is difficult to speak to children; but it is easy to offer things themselves, show them and finally name them. Consequently, since we cannot speak to them, nature itself may speak and imprint itself in their eyes, ears, noses, palates and hands. ${ }^{54}$

Teaching by object lesson is the high road to language. The epistemological framework of the reformed pedagogics implies that children learn to speak only in so far as they become a surface subjected to the forces of empirical sense perception. What is more important, though, is that the above quote clearly shows how reformed pedagogics aimed at the automation of the links among words, concepts, and things. Buried in these lines is nothing less than a method designed to link optical streams of sense data to acoustic streams of sense data and acoustic streams to concepts or meaning so that concepts or meaning in turn may evoke optical streams anew and thus close the circle. At this point, two tendencies in the pedagogy of Comenius become apparent: "The first is the centrality of oral-aural-optical development in his conception of the process of language-growth; the second is the continuity of language and thought, language and meaning, and language and sense experience. Comenius saw the speech behaviour of the young child as holding the key to his or her entire linguistic formation; he saw it as the foundation on which the subsequent development of reading and writing competence is to be based." 55 Children, he says, ought to have a "Lucidarius [i.e., a picture book] containing everyday things, known from their home, and their corresponding names, but first of all, a truly vivid alphabet." ${ }^{56}$ Comenius, himself the author of such a book, addressed his illiterate readers in its opening lines:

Before all things, thou oughtest to learn the plain sounds, of which mans speech consisteth; which living Creatures know how to make, and thy tongue knoweth how to imitate, and thy hand can picture out. Afterwards we will go into the world and we will view all things. Hear thou hast a lively and vocal Alphabet. ${ }^{57}$

In these lines, the acquisition of letters is folded back upon the acquisition of language. Moreover, as alphabetization doubles the child's initiation into language, the alphabet itself turns into a double of the already familiar world.

This book where the alphabet is transformed from code to interface, as it were, is Comenius' groundbreaking primer and textbook Orbis sensualium pictus ("A World of Things Obvious to the Senses") of 1658. Departing from the sounds of letters, Comenius elaborated his predecessors' method into a fully developed tool of alphabetization, where every letter was tied not only to a sound but also to a picture (a cat, a dog, a crow, etc.) that represented the "natural" sound of each letter. This was not merely a trick of the trade among pedagogues; like Ickelsamer, Comenius was aware of the perils of the 
medium of writing. Since books consist of letters that signify words and images and not of words and images themselves, their consumption, if achieved at all, is never instant and always mediated. For such reform pedagogues as Ickelsamer and Comenius, the bottleneck of signifiers that troubled the media specialists of humanism was also the bottleneck that threatened to block universal alphabetization. "What is offered to pupils through books, those mute teachers, is in reality mute, obscure, imperfect," Comenius feared. ${ }^{5}$ And since this was the case, he held learning to read to be an equally hard and difficult enterprise. While "youth acquire the skills of reading and writing only at great cost" it would be "profitable to sweeten these first bitter roots of education with the help of an artifice in order that children would not notice their acridity" and that is something "that can only be achieved if this rather hard work is transformed into play." 59

The artifice in question was the method materialized in the Orbis pictus. If universal literacy was to be achieved, a "vivid alphabet" had to be invented and promoted. Designed to supplement a writing that was basically imperfect, mute or even dead, Orbis pictus gave life to alphabetic signs by way of sounds from nature and pictures from life. Like its predecessors in the sixteenth century, then, this primer promised to save people from the traditionally slow and difficult reading instruction. According to the author, Orbis pictus supplied pupils with everything they needed in order to learn how to read by themselves. ${ }^{60}$ Signs, sounds, and pictures cooperate, and, as the child has gone over the whole book,

reading cannot but be learned; and indeed too, which thing is to be noted, without using any ordinary tedious spelling, that most troublesome torture of wits, which may wholly be avoyded by this Method. For the often reading over the Book, by those larger Descriptions of things, and which are set after the Pictures, will be perfectly able to beget a habit of reading. ${ }^{61}$

Since alphabetization in prior centuries had done nothing to erase the alien qualities of writing, reformed pedagogics did everything in their power to cover up these qualities. With Orbis pictus, "torture" yields to "play" in alphabetization, which in practice meant that the pattering of chains of nonsense syllables ceased. Saving children from the materiality of syllabic sets, Comenius simply supplied them with an alphabetic technology that aimed at making the acquisition of writing and reading as easy as that of speaking and hearing. Thus his alphabet had the immediate advantage of evoking the concept or "meaning" of "things," while merely listening to "the sound of a voice." 62 Instead of struggling with mind-boggling signifiers, readers came under the influence of a, as it were, hallucinated signified.

Once again, one cannot help but remark that the formal outlines of this alphabetic technology are an almost perfect analogue to the sensorial characteristics which pious humanists ascribed to the Word. Like Ickelsamer before him, Comenius developed a method of alphabetization that seems designed to produce the kind of effects that were said to abide in the Protestant Word. The "vivid alphabet" was simply a technological substructure beneath the phenomenal superstructure of the Word, where Christ, according to its architect, "lives, breaths, speaks to us," or at least to those who "are all eyes and 
ears." ${ }^{33}$ Readers who learned to read with the Orbis pictus were thus more than prepared to experience the phantasmatic qualities of Word. As one of Comenius' supporters in the Swedish literacy campaign testified, "The voice of the Lord rings in my ears, and sometimes it does not even allow me to sleep. While I sit in peace and quiet with my intimate friends, it whispers in my ears, so that my heart is moved and the breath is heard." 64 Precisely as the primer promised, the reader trained by Orbis pictus was given access to "a lively and vocal Alphabet."

Consequently, after 1658, the prospects for universal alphabetization suddenly seemed better than ever before in Northern Europe. The hypermedium of writing was served by a congenial new alphabetic technology that, in turn, could take advantage of the old Lutheran home learning-system, where every householder was expected to preside over Bible-readings. And yet there were no signs that universal literacy was in the offing. ${ }^{65}$ Not even in Sweden, where several serious attempts were made in a number of dioceses, can anything that is even close to mass literacy be registered in the decades before $1686 .{ }^{66}$ What, then, made the campaign following the Swedish Church Law such a success? In order to answer that question we have to explore how the different parts of the apparatus of literacy finally fell into place in Sweden. What was the strategy behind alphabetization? Which techniques were deployed? And what can their deployment tell us about the function of literacy in Sweden around 1700?

\section{Alphabetization and Swedish discipline}

In the 1680 s, Swedish educational literature came under the spell of a new pedagogic ideal. If teachers in earlier times had approved of flogging as a necessary element in primary education, ${ }^{67}$ they now preached kindness and encouragement as means to make children perform. Johannes Gezélius, bishop in the diocese of Åbo in Finland, demanded that "the teacher also has ... to be sober, and teach the children with kindness, making them learn not by means of threats and punishments, but through tenderness; otherwise they will not love the Book, but will become bored of it and wish to escape from learning." ${ }^{8}$ Another adherent of the new ideal was his colleague Herman Schröder. While a believer in the importance of corporal punishment, Schröder made an exception for education: "As the boy has to be chastised by the rod because of the faults of naughtiness, so that roguishness may be subdued in time, one has, as for lessons and arts, on the contrary to try not to imprint these in the child by severity, cruel countenance along with hits and blows, for out of that comes more weariness of and displeasure with learning than pleasure and love, without which one is practically unable to learn anything." ${ }^{69}$

A third advocate of gentleness in education, Bishop Jesper Swedberg, declared in one of his many treatises that he always had "liked their instructions best, whose objective it is that youth shall learn with pleasure and in a happy mood, with delight and joy." "70 According to the bishop: "Youth is tender, frail and weak" and "what ought to be learned, is hard, heavy and difficult." Swedberg also argued that one "must not make their burden heavier than they are able to carry. And this without force, without pressure, without blows; always with docility, gentle persuasion, pleasure and play." ${ }^{71}$ Again 
and again, he repeated that pleasure promotes learning, drawing on the bitter experiences of his own school days, when he had been forced to learn the syllables of words he didn't understand while being flogged and shouted at.

The new pedagogic ideal, in other words, was that of reformed pedagogy. The fact that the authors of reform pedagogical treatises were all bishops is no coincidence. Since almost all elementary education in Sweden was run by the church, bishops were responsible for the state-of-the-art in secular as well as religious learning. Thus, they also had the power to turn their new ideals into practice. Disseminating primers and textbooks from newly established print shops in every diocese, these bishops made Lutheran home learning serve the curriculum of reform pedagogy. The primal scenes of alphabetization are telling:

Another proof of my good memory and quickness was that I, while being sick, learned from my mother, not only how to read in a book, but also how to sing psalms, read prayers and some parts of the catechism, and all this was unknown to my sweet father, who almost always found me in bed. For this reason he blessed my dear mother, rejoiced in his heart and gave me a book, called Orbis Pictus, to enjoy myself. And this happened in 1685, as bishop Spegel came to Skara ... . In 1686 I was ill throughout the winter once again, but Orbis Pictus was always with me in my bed. I learned to read it by heart, though I did not understand a word. ${ }^{72}$

If pedagogues feared that traditional schooling made children hate "the Book," Orbis pictus was obviously a work that sought to produce the opposite effect. Although children like Andreas Olaus Rhyzelius did not understand much of the world that was presented to their eyes and ears, the primer of reform pedagogy energized its reader in its home and, accordingly, made it love "the Book" without any support from the institution of school. As the case of Rhyzelius makes clear, this love was so strong that it did not only secure alphabetization and thus the circulation of the Word, it could also turn readers like little Andreas into future bishops. ${ }^{73}$

The translator and publisher behind the first Swedish edition, in 1682, of Oribs pictus was Johannes Gezélius. ${ }^{74}$ In the diocese of Åbo (Turku), Gezélius had created what was virtually a media network of his own. Having established a paper mill and a private printing shop, he issued his own primers and textbooks for popular education and for the schools of the diocese. At the same time, he had the school curriculum reorganized in accordance with his own reform program as outlined in Methodus informandi of 1683. Thus, Gezélius came to control every part of the pedagogical process, its material substrate, its curriculum, and its practice. As the title of his school order indicates, the Bishop believed in "method" in education, and the method intended was that of Comenius' in Orbis pictus. Inspired by Comenius' combined primer and textbook, Gezélius had written his own in hopes of having it accepted as an addendum to an upcoming church ordinance. Although this did not come to pass, the diocese of $\AA$ bo and its reform pedagogy nevertheless came to influence the Swedish Church Law of 1686. More importantly, however, the media network of Åbo seems to have provided the model for 
the entire reorganization of popular education after 1686. The literacy campaign in Sweden can thus be traced back to Gezélius' relentless drive to foster a population of readers by using Orbis pictus and reformed pedagogy. ${ }^{75}$

This does not mean that it is possible to prove that Comenius' primer was used by every farmer and weaver after $1686 .{ }^{76}$ My point is rather that the alphabetic technology and reform pedagogy of Comenius formed a new historical apriori for mass literacy in the Swedish state. Already, in 1628, Comenius had proposed a "ludi literarii" or a "play with letters ... where the last words designate that the training of youth should in itself be perceived as sweet, pleasant and nothing but a game and a pastime by those who teach and those who are taught as well." 77 Those words initially had little effect as Comenius was translated into Swedish in the 1640 s, but, after 1686, his theories came to dominate popular reading instruction.

Jesper Swedberg, who urged that every schoolmaster should be a "master of game and play," provides yet another example wherein reformed pedagogics are juxtaposed to the old practice of Lutheran home learning. Besides the usual Bible-readings he presided over in front of family and servants every Sunday, Swedberg relates that he has

now started to use a device to teach them their catechism, where children and servants every evening after dinner have to take pieces of paper; on some is written reading, while others are blank. Those who get reading have to read a paragraph in the catechism, which will afterwards be explained by me with an admonition to live in accordance to it. And so I teach and strengthen myself and them in the knowledge of faith and true godly exercises. ${ }^{78}$

In this paragraph, Swedberg adheres almost literally to Church law. Precisely as the law prescribes, he teaches his household to read the Word of God as it is displayed in the Catechism. ${ }^{79}$ What is critical here, however, is the practice developed to fulfil this duty. Obviously designed as a game, Swedberg's reading exercise inculcates learning, comfort, and commands but under the guise of play. As he points out himself, many people are lost in thought during sermons in church, but "that does simply not happen in the godly and edifying examination of the catechism." 80 Where sermons address a mute collective, an examination of the catechism involves individuals who must speak in order not to incur criticism. Criticism, however, can turn out to be harmful for learning. While providing for a more effective indoctrination than sermons, examination runs the risk of producing fear, and fear provides poor soil for performance.

However, it is this problem that the moments of play in Swedberg's examination are designed to overcome. Where traditional examination might appear frightening, Swedberg's easygoing reading exercise facilitates learning. Yet this cannot change the fact that an examination is still an examination and getting the note reading can still be threatening for beginners. While Swedberg's method is finally unable to guarantee pleasure in reading, it must transfer the authority to decide who has to read from the teacher to chance alone. Hiding behind the function of chance, Swedberg cannot be equated with the authoritarian schoolmaster of the old days who made pupils read in fear of the rod, rather he stands out as the tender shepherd who explains the Word on the behalf of his flock. 
How are we to understand this vogue for games and pleasure in elementary Swedish education around 1700? In the reading practice developed by Swedberg, the pleasure principle of reformed pedagogy seems to have a double function: first, to lure people into reading and, second, to cover up for the compulsory element in the campaign. But why must compulsory reading instruction be made invisible in the first place? Why do not bishops, teachers, and householders simply order people to learn how to read in the name of the law? At first glance, these questions point towards the pedagogical conditions peculiar to Sweden around 1700. In order to achieve a minimal level of success, the hard reading instruction of old times required children to attend school for most of the year. In a kingdom like Sweden, where few formal schools existed, this was practically impossible. If reading were to prosper in the kingdom, it had to be achieved through other means; namely, by Lutheran home instruction.

This system, however, ran counter to traditional methods of instruction, where severe punishment and rote learning of syllables reigned. On the contrary, precisely those practices had to be avoided if mass literacy was to be achieved, and that is why Swedish educational treatises never stop denouncing violence in education. Instead, officials in the educational system launched a Comenian reform pedagogy, banning severe punishment and correction from pedagogical practice, and they promised to teach everyone to read by way of the pleasure inherent in a vivid alphabet. From the point of view of the bishops, who otherwise had no problem with corporal punishment, reformed pedagogy seemed to provide the best answer to the difficult and pressing question of how to get a population of illiterate country people to become literate, partly because its "method" was commensurate with the practices of home learning and partly because reformed pedagogics promised that letters that produced pleasure would bring about universal literacy almost by themselves.

However, reformed pedagogy was, as well, a technology of power. In fact, in terms of power it can be seen as one of the many faces of what Michel Foucault called "discipline," or the vast and almost invisible system of small scale techniques and petty practices designed to control larger units like institutions and populations, while making them docile and productive. ${ }^{81}$ In many ways, discipline seems to be the modern opposite of a traditional form of power like sovereignity or the power of the prince. While sovereign power applies to the land and to what it produces, discipline applies to bodies and what they do. Where sovereign power is repressive and circumscribing, disciplinary power is productive and creative. And while sovereign power is possessed by a presence at the center of society, where it operates through brilliant spectacles and public rituals, disciplinary power works in strictly delimited spaces where it materializes in the form of meticulous rituals and privatized forms. The object of discipline is the individual body and the performance of individuals as individuals; its tools are training, examinations and surveillance; its sites are the army, the family, schools, etc. While sovereignity was a form of power that dominated in premodern times and discipline is a modern form, the former was not simply replaced by the latter. According to Foucault, the sudden dissemination of discipline during the seventeenth century is due to its flexibility and capacity to merge with sovereign power in absolutist states. In fact, the political history of power in the modern West is in many ways a story of a scarcely secret overtaking, 
where discipline gradually invaded the state apparatuses of sovereigns, altering their mechanism and imposing new procedures. ${ }^{82}$

At first, any analysis of Swedish alphabetization in terms of discipline only seems to repeat what we already know: reform pedagogy is preferred because of its productivity. However, there is more to discipline than efficiency. Where previous research conceived of reading instruction as a means to confirm faith or to consolidate the absolutist state, the identification of Swedish alphabetization as disciplinary makes it possible to decipher another and perhaps more pertinent function of alphabetization; namely, that subjecting bodies to extensive alphabetic training and recurrent examinations is a means to produce individuals or subjects. ${ }^{83}$

As Swedberg's statements make clear, examination as a practice dissolves collectives. Instead, it forces everyone to perform individually, and individual performance is what constitutes individuals. The form of power applied in the Swedish reading examination categorizes the individual according to a norm — skills in reading and rote learning respectively — and marks it with its own individuality on basis of its level of performance. At the same time, while the content of the reading exercises is made up of the catechism's definitions of God and man, on the level of discourse the reading examination ties individuals to their own identity, in terms of Christian conscience and self-knowledge. Thus, by narrowing the gap between practice and discourse, alphabetization in Sweden appears as a charged site where individuals are constituted as subjects through power relations. ${ }^{84}$

However, discipline does not only make use of examination in order to individualize. Equally important are practices that concern the archive. As a final example from Swedberg's memoirs will show, disciplinary power furnished the functionairies of the Swedish literacy campaign with small techniques of knowledge designed to solve large scale problems. While working as a chaplain in the Royal Lifeguard in the 1680s, Swedberg claims that he examined the soldiers "in a most docile and gentle" manner, for "this is the way to approach your listeners, and under no circumstances [you must] confuse and torment them with dry and meagre questions and intricacies." ${ }^{85}$ In order to speed up alphabetization, he promised every soldier who would be able to read by the next inspection a gift (a catechism of their own). As nearly 600 of the 1200 men then passed this exam, Swedberg was more than satisfied: "That is how you get the rider and the soldier to read; not with threats and persistence, not with the rod and the stake." ${ }^{86}$ However, as he turns to the king in order to secure means to pay for the books, the reform pedagogue suddenly finds himself with the rod and the stake in his hands:

Giving me the ducats, the king asked me whether all of them were that diligent and willing to read. Now, from the day I first came to the regiment I had recorded the reading and life of everyone. I identified a reluctant and averse crowd that kept away from examinations and another one that lived a dissolute life. The king took the record from me and ordered colonel Fägerschöld to have all of them brought to the stake. That caused alarm in the camp. And so many stakes could not be found in a hurry. I reduced the punishment; only the most averse, vicious and negligent were called. And a lot of stakes were raised at 
Pålaksbacken with a rider at every single stake. Afterwards they became submissive and pious. Vexatio dat intellectum [pain brings understanding] the proverb goes. ${ }^{87}$

Always ready to deliver another bloody spectacle, sovereign power procures universal literacy by torturing bodies. What is interesting, however, is not the discontinuity between forms of power, but rather the smooth transition from one form to another. Where discipline fails to deliver, authoritarian punishment stands ready to take over, and this cooperation clearly exemplifies how discipline and sovereignty intersect in the seventeenth century absolutist state. As Swedberg's attitude indicates, early modern reform pedagogy is about effectiveness rather than philanthropic morals. However, it is important to note that this intersection takes place at a strictly technical level, namely that of the archive. Ever since he entered into the regiment as a chaplain, the hand of the pedagogue has meticulously "recorded the reading and life of everyone" (almost 1,200 men) and has stored the records in an archive in order to activate them when necessary. This archive provides the technical conditions of the possibility of disciplinary power, partly because individualization in such large numbers would be impossible without it and partly because documentation promotes individualization in itself.

As Foucault has argued cogently in Discipline and Punish, the ritual of examination produces dossiers containing minute observations on every single individual. ${ }^{88}$ Not only do such records introduce "individuality into the field of documentation," but records and archives also "constitute the individual as effect and object of power, as effect and object of knowledge." ${ }^{99}$ The well-disciplined hand of the pedagogue that worked diligently from day one was itself a rule-governed part of that machinery of individualization. Making use of the techniques of discipline, the Church Law of 1686 mandated that every rural dean and vicar document, in addition to the old registers of births, marriages and deaths, the catechetic knowledge and reading skills of everyone, "specific records on all their listeners, from house to house, from farm to farm, and gain information on their progress and knowledge." ${ }^{0}$ The vast, meticulous documentary apparatus that was instituted by these words was essential to the success of the reading campaign. The records made every single individual of the population visible as an individual, and the mnemotechnical devices made the recurrent examinations productive. In order to produce subjects, Swedish alphabetization relied on the power of its archive.

Thus, via an examination of techniques and technology rather than of the religious context and content of the literacy campaign, we have been able to trace a genealogy of the apparatus of literacy in early modern Sweden. While the success of the campaign was due to the apparatus itself in all its wonderful, albeit contingent, coherence, it is tempting to identify disciplinary power as its single most important element. As is obvious, the historical shift from a sovereign form of power to discipline is an analogue of the shift from traditional to reformed instruction in letters, and it was under the latter that universal literacy first was achieved. Is it possible, then, to identify discipline not only as a set of technical devices, but as a clue to the redefinition of the historical context of Swedish alphabetization in itself?

As the only dyslectic in history to launch a campaign of universal alphabetization, ${ }^{91}$ 
Charles XI of Sweden certainly knew what he was demanding from his subjects. While being recognised as a devout and pious Christian by historians of later times, the king, who had wept over the stubborn materiality of signifiers throughout his childhood, was known in his day as an enemy of the church. Since the law of 1686 circumscribed the autonomy of the Swedish church, turning it into a state-run "bureaucractic department of salvation," many priests felt that the church had lost its independence. ${ }^{92}$ This indicates that the context relevant to universal literacy may not be religious consolidation, but rather the reconstruction of the Swedish state apparatus of which the Church Law formed a part. Introducing autocracy in Sweden, Charles XI devised a state reform that has been interpreted as an expression of a "revolution from above" and that made uniformity and centralization vital issues. ${ }^{93}$ However, there is more to the recreation of the Swedish state than shifting trends in European forms of government. Above all, the state reform was triggered by Sweden's weak geo-political position. Hence I would like to suggest yet another context for state reconstruction and — therefore- - universal literacy as well. This context is war, and the evidence I would like to invoke is - once again forms of power wherein the link between the reconstruction of the state, the literacy campaign and war was articulated on the technical level of discipline.

During the Thirty Years' War, Sweden ascended into the ranks of the great European powers, a position based on its military accomplishments. ${ }^{94}$ Because of its small population and underdeveloped economy, however, the country was at pains to defend this position over the long run. This was clear not only to its enemies but to its king as well, who consequently introduced defensive warfare as the country's military policy in the 1670s. If Sweden was not to lose its Baltic empire, it had to invent a new means for defending itself. Consequently, the old military state was rebuilt into a new one, wherein all institutions of any significance - military, legal, mercantile, and religious - were reconstructed in order to strengthen the central power. As the strategy behind the reform was a far reaching rationalization of the resources that enabled total mobilisation, Sweden became a wholly militarized society. ${ }^{95}$

However, while total mobilisation was not a new objective, the techniques used to attain it certainly were. Sweden under Charles XI became the scene of an implementation of a new form of power that calculated with minimum expenditure and maximum efficency. This form of power was discipline. ${ }^{96}$ While discipline was a technology that worked on individual bodies, it had the advantage of producing large-scale results. To be more precise, it was "a tricky combination in the same political structures of individualization techniques and of totalization procedures." 97 This made it especially attractive to a state like Sweden where resources were scarce and where the population was the single most important asset. Interestingly enough, Foucault has suggested that we should not "consider the modern state as an entity that was developed above individuals, ignoring what they are and even their very existence, but, on the contrary, as a very sophisticated structure in which individuals can be integrated, under one condition: that this individuality would be shaped in a new form, and submitted to a set of very specific patterns." ${ }^{98}$

Seen from this perspective, early modern state construction and the early modern disciplining of individuals cannot be separated from each other, rather they appear as different aspects of the same phenomenon. In the case of Sweden, this means that the 
(re)making of the state and the making of subjects coincided in the techniques of discipline. While those techniques can be found in a number of sites and institutions in late seventeenth-century Sweden, alphabetization appears as especially important since it juxtaposes practice and discourse, reading skills and Christian identity. In every sense of the word, then, the apparatus of literacy, wherein a new kind of writing, a reshaped alphabetic technology, and a new technology of power met, was of state interest.

Hence, war or the militarization of society, not consolidation of Lutheran faith, is the critical context for the Swedish literacy campaign. But if the constant threat of war explains the need for state reconstruction, it does not explain how discipline could emerge in Swedish society in such a short time. While discipline, as a technique, was certainly in play since antiquity, it was not until the seventeenth century that it simultaneously came to prominance in a number of different fields. Foucault mentions a few sites and institutions that appear to have been of special importance for the development of discipline as a universal technology of power, of which the army was key.

Here the bond with antiquity is apparent, since discipline was a distinctive feature of the Roman army. The reintroduction of discipline in the early modern period was accomplished by humanist-military figures such as Maurice of Orange and his cousin John of Nassau who turned to Aelian and Vegetius and other Roman writers on the art of war in order to improve the effectiveness of armies. ${ }^{99}$ Trying to adapt themselves to the classics, the cousins started a military reformation that gave rise to major changes in the tactics and strategy of war. In 1594, the Dutch army perfected the technique of the "salvo," which involved each rank firing its muskets simultaneously at the enemy, and then retiring to reload, while the other nine ranks followed suit, creating a continuous hail of fire. But to perform this manoeuvre in the face of the enemy called for superior courage, perfect coordination, and great familiarity with all the actions involved.

Constantly training, the Dutch troops followed the manuals produced by the cousins, where a numbered sequence of pictures illustrated the various manoeuvres required to handle military weapons and organize troops for war. At the same time, soldiers were required to adhere to the spiritual ideals or virtues of discipline. Training, order, and stoic technologies of the self fashioned a model soldier whose outer strength was balanced by inner virtues. The soldier was subjected to blind obediance, but, at the same time, was adressed in a "liberal and friendly" way by his commander, whose duty it was to "bring him in a happy mood." 100 At every possible level, discipline permeated the Dutch military reform.

However, if it was the princes of Nassau and Orange who reintroduced discipline in the early modern army, it was the privilege of their brothers in arms in Sweden to turn it into a success on a grand scale. ${ }^{101}$ John of Nassau visited Sweden in 1601-02 and gave advice as to how the Swedish army could be improved, but the main influx of Dutch expertise came two decades later. On his tour through Germany in 1620 the Swedish king, Gustavus Adolphus, visited all military fortifications and organizations of importance. Like Maurice and John, he realized that disciplined bodies resulted in tactical advantage on the battlefield. Building his army using native rather than mercenary troops, the king himself supervised the drilling of Swedish peasants and farm hands. Units recruited abroad were made to watch demonstrations of the "Swedish order of 
discipline" and then had to practice until they performed perfectly. ${ }^{102}$ Efforts were made to keep the troops busy all the time and when work was over service began, since the strictly scheduled drill of the Swedish army was constantly punctuated by pious exercises. $^{103}$

Gustavus Adolphus' disciplined soldiers paved the way for innovative tactics, and, as a result, the army proved victorius in one battle after another during the Thirty Years' War. Practically overnight, Gustavus Adolphus was hailed as "the new risen Starr" and "the millitary mirrour of our times." 104 Books like Monro His Expedition, written by Robert Monro, a former Scottish mercenary in the Swedish army, and The Swedish Intelligencer demonstrated Adolphus' strategy and tactics to readers all over Europe. Moreover, a book published in London in 1632 under the telling title The Swedish Discipline, set out the king's "Religious, Civile, And Military" practice, covering every aspect from daily prayers to building fortifications. Gustavus, "that miracle of Souldiers," had set new technical standards, and his methods continued to receive high praise long after his death.

As an institution, then, the Swedish army played a key role in the seventeenth-century development and dissemination of discipline as a technology of power. Fifty years later, Charles XI could still benefit from this fact, since the army retained, for the remainder of the century, the organisation Gustavus Adolphus had given it in the 1620s. Because of his dyslexia, the young Charles XI was quick to adopt the non-theoretical, or military part of his education, which was directed by officers who had served in the Thirty Years' War. From childhood on, he grew accustomed to exercises and drills, and, unlike other sovereigns of the time, Charles XI preferred to exercise a regiment to giving a spectacular feast. The harsh reality behind such rustic attitudes was the weak geopolitical position of Sweden.

Throughout his grown-up life, Charles worked diligently to perfect the organisation of Sweden's military system. Since all other problems were subordinated to this objective, it was only natural that military solutions were applied to non-military fields as well. The "new drill" that Charles XI taught his army can thus be traced into other parts of society. When founding new cities, for instance, the king applied city plans to the grid-structure of the Roman army camp. When founding new industries, Charles sought not to develop the economy at large, but rather to see to his army's need for uniforms or guns. When reforming the legal system, the king made sure that it would facilitate royal, or military, command and control. In sum, Charles XI had a military order projected over society, and, thanks to the venerable institution of the Swedish army, where discipline was, if not invented, at least extremely well developed, military organization and disciplinary practices were able to spread into every corner of civil life in the final decades of the seventeenth century. In fact, the activities of the Swedish soldier-king seem to exemplify the military dream of society, a dream of docile bodies, of constant coercion, and of permanent training. ${ }^{105}$

Mass literacy, then, began as a preparation for war. "A souldier without letters is like a ship without Rudder," wrote Robert Monro, the adherent of "the swedish discipline." 106 The point, however, is not that the population of Sweden had to learn how to read in order to become soldiers. The literacy campaign formed a part of an 
all-embracing militarization of society, which, with the aid of disciplinary practices, made the "individual" its immediate object. To put it bluntly: alphabetization turned masses into "individuals" and individuals into subjects of the Swedish military state. Without such subjects, this state would have ceased to exist. The apparatus of literacy, as it took shape in Sweden around $1700 \mathrm{AD}$, thus had a very specific function, namely to secure the existence and the prosperity of "individuals" and the state at the same time.

\section{Conclusion}

As R. A. Houston wrote in 1996, "The Reformation saw the beginning of a momentous shift from the closely restricted reading and writing of the Middle Ages to the mass literacy that Westerners have come to regard almost as a birthright." 107 Today, after so many ruptures in media technology and education, we may no longer take that birthright for granted. Indeed, the future of mass literacy and the literature that feeds it has been called into question more than once. At the same time, though, the central problems of mass literacy might be less oriented toward the future than the past. How much do we in fact know about the birth of our "birthright," beyond the grand narrative of the momentous shift that started with the Reformation? What do we know, for instance, about the historical roots of the practices and technologies that shape us as we engage the alphabet today? To understand our present situation, so charged by ruptures of technology, we must dig into history in the face of media and its practices. This essay has attempted to do so by examining the unexpected beginning of mass literacy in early modern Sweden. Exploring the connections among media, alphabetic technology and power, we have reconstructed the apparatus that made universal literacy possible in the first place. To be more precise, we have uncovered the militarization of society as an enabling condition of early modern mass literacy. Rather than bringing our examination to its end, this insight opens the door for new and difficult questions concerning ourselves and the apparatuses of literacy currently in use. What does it mean that mass literacy as we know it derives from a military context? Does the disciplinary origin of reformed pedagogics affect its contemporary counterpart? Is there in fact a disciplinary remainder in the alphabetic technology we have inherited, in the very practices that shape us into readers? Since western societies of today still consider universal literacy necessary to procuring the prosperity of both individuals and society at large, we ought to take such questions seriously. 


\section{Notes}

1 Despite its historical priority, the Scottish national literacy campaign did never achieve mass literacy. See Rab Houston, "The Literacy Campaign in Scotland, 1560-1803," in Robert F. Arnove and Harvey J. Graff, eds., National Literacy Campaigns: Historical and Comparative Perspectives (New York: Plenum, 1987), 49-64.

2 For the statistical evidence, see Egil Johansson's ground-breaking thesis, En studie med kvantitativa metoder av folkundervisningen i Bygdea socken 1845-1873 (Ph. D. diss., University of Umeå, 1972). For a short account of the campaign, see Johansson, "The history of literacy in Sweden," in Harvey J. Graff, ed., Literacy and Social Development in the West: A Reader (Cambridge: Cambridge University Press, 1981),151-182. Johansson's various essays on the subject have been collected in Daniel Lindmark, ed., Alphabeta varia. Orality, Reading and Writing in the History of Literacy: Festschrift in honour of Egil Johansson on the occasion of his 65th birthday March 24, 1998 (Umeå: Institutionen för religionsvetenskap, Umeå universitet, 1998). Johansson's research and the Swedish history of popular education are presented in their national and international context by Johansson's pupil Daniel Lindmark in Reading, Writing and Schooling: Swedish Practices of Education and Literacy, 1650-1880 (Umeå: Institutionen för litteraturvetenskap och nordiska språk, Umeå universitet, 2004), 30-46.

3 Lindmark sketches a shift from literacy rates to literacy practices in Johansson's research. However, this shift has not brought about any studies by Johansson's or by his pupils' concerning the first literacy campaign. See Lindmark, Reading, Writing and Schooling, 3941.

4 Ibid., 35.

5 Swedish historians such as Birgitta Odén and Bengt Sandin have been troubled by Johansson's unwillingness to go beyond the immediate context of his material. An alternative view has been presented by Odén, who argues that the literacy campaign can be understood as a means for the the early modern power state to force its ideology upon the population, see Odén, "Läskunnighet och samhällsförändring," Forskning om utbildning 1 (1975): 17-31.

6 Egil Johansson, "The History of Literacy in Sweden," 156.

7 While Johansson is aware of the presence of the reform pedagogy in the campaign, Lindmarks study contains no references to Comenius or Ratke whatsoever, which is somewhat surprising, see ibid., 163; Lindmark, Reading, Writing and Schooling, passim.

8 Michel Foucault, "Nietzsche, Genealogy, History," in Language, Counter-Memory, Practice: Selected Essays and Interviews, Donald F. Bouchard, ed., trans. D. F. Bouchard and Sherry Simon (Ithaca, N.Y.: Cornell University Press, 1977), 142.

9 The method under discussion is thus indebted to Foucault's "genealogy," and much like him I am looking for historical affiliations or resonances rather than origins. Foucault characterized genealogy as "an examination of descent," which permits the discovery, under the unique aspect of a trait or a concept, of the myriad events through whichthanks to which, against which — they were formed," Foucault, "Nietzsche, Genealogy, History," 146. However, where Foucault was concerned with relations of power, my proposed genealogy is defined by the formal relations within and among media as well as by relations of power.

10 Kyrkio-Lag och Ordning (Stockhom, 1687), chap. 2, \$. 10: "drifwa med flijt ther på at Barn/ Drängar och Pijgor/ lära läsa i Book, och se med egna ögon hwad Gud i sitt helige Ord biuder och befaller [...]." Cf. chap. 24, \$. 11, 22, 31, 33. Unless otherwise indicated, all English translations are mine.

11 See Wolf Peter Klein, Am Anfang war das Wort: Theorie- und wissenschaftsgeschichtliche Elemente frühneuzeitlichen Sprachbewußtseins (Berlin: Akademie Verlag, 1992).

12 See Jerry H. Bentley, Humanists and Holy Writ: New Testament Scholarship in the Renaissance (Princeton, NJ: Princeton University Press, 1983). 
13 For this perspective, see Manfred Schneider, "Luther with McLuhan," in Hent de Vries and Samuel Weber, eds., Religion and Media (Stanford, CA: Stanford University Press, 2001), 198-215.

14 Paraclesis, in Hajo and Annemarie Holborn, eds., Erasmus Ausgewählte Werke (München: C.H. Becksche Verlagsbuchhandlung, 1933), 140. On Paraclesis and writing, see the important discussion in Brian Cummings, The Literary Culture of the Reformation: Grammar and Grace (Oxford: Oxford University Press, 2002), 102-111.

15 For the theoretical approach, see Michel Foucault, "What is an author?," in J. V. Harari, ed., Textual Strategies: Perspectives in Post-Structuralist Criticism (Ithaca, NY: Cornell University Press, 1979), 141-160. On humanism and authorship, see Kevin Dunn, Pretexts of Authority: The Rhetoric of Authorship in the Renaissance Preface (Stanford, CA: Stanford University Press, 1994), 9-10.

16 A. J. Minnis, Medieval Theory of Authorship: Scholastic Literary Attitudes in Later Middle Ages (London: Scolar Press, 1984), 216.

17 See Cummings, The Literary Culture of the Reformation, 105.

18 Paraclesis, 141: "pium ac promptum animum"; "simplici puraque [...] fide".

19 Paraclesis, 142: "Vehementer enim ab istis dissentio, qui nolint ab idiotis legi divinas litteras in vulgi linguam transfusas, sive quasi Christus tam involuta docuerit, ut vix a pauculis theologis possint intelligi, sive quasi reiligioni Christianae praesidium in hoc situm sit, si nesciatur".

20 Ibid., 142.

21 Foucault, "What is an author?," 150.

22 Quoted in Lisa Jardine, Erasmus, Man of Letters. The Construction of Charisma in Print (Princeton, NJ: Princeton University Press, 1993), 50.

23 Paraclesis, 146: "Qui quod pollicitus est se semper nobiscum fore usque ad consummationem saeculi, in his litteris praecipue praestat, in quibus nobis etiamnum vivit, spirat, loquitur, paene dixerim efficacius, quam cum inter homines versaretur. Minus videbant, minus audiebant Iudaei, quam tu vides et audis in euangelicis litteris, tantum ut oculos et aures afferas, quibus ille cerni et audiri possit."

24 Ibid.: "Hae tibi sacrosanctae mentis illius vivam referunt imaginem ipsumque Christum loquentem, sanantem, morientem, resurgentem, denique totum ita praesentem reddunt, ut minus visurus sis, si coram oculis conspicias."

25 Ibid.: "Sive cupimus residem ac languescentem animum expergefacere lectione, quaeso, ubi reperias igniculos aeque vivos et efficaces?"

26 S. Gregorii Magni registrum epistularum libri VIII-XIV, ed. Dag Norberg, Corpus Christianorum. Series Latina, 140 A (Turnholti: Brepols, 1982), XI, 10, 874: "Nam quod legentibus scriptura, hoc idiotis praestat pictura cernentibus, quia in ipsa ignorantes vident quod sequi debeant, in ipsa legunt qui litteras nesciunt; unde praecipeque gentibus pro lectione pictura est." Cf. Celia M. Chazelle, "Pictures, books and the illiterate: Pope Gregory I's letters to Serenus of Marseille," Word \& Image 6 (1990): 138-53.

27 See Lawrence G. Duggan, "Was art really the 'book of the illiterate??," Word \& Image 5 (1989): 227-251.

28 On the Renaissance as a point of departure for the process where media constantly refashion one another, see Jay David Bolter and Richard Grusin, Remediation: Understanding New Media (Cambridge, Mass.: MIT Press, 1999), 21-23.

29 See Cummings, The Literary Culture of the Reformation, 109.

30 Cf. Bolter and Grusin, Remediation, 19.

31 The literature on the subject is immense. For the best scholarly treatment and an extensive bibliography, see Johannes Burkhardt, Das Reformationsjahrhundert. Deutsche Geschichte zwischen Medienrevolution und Institutionenbildung 1517-1617 (Stuttgart: Verlag W. Kolhammer, 2002), 16-76. 
32 For the blind spot in media studies, see Schneider, "Luther with McLuhan," 198-215. For an important exception, however, where the prefaces and glosses in Luther's printed bible are used to reconstruct his reading-program, see Mark U. Edwards, Printing, Propaganda and Martin Luther (Berkeley, CA: University of California Press, 1994), 109-130.

33 The status of the preface is underlined by the fact that Froben had a separate version printed in 1519 and later it was translated into several vernaculars, among them Swedish (1611).

34 Hence, what Erasmus has to say on the living presence of Christ in his gospel reappears almost word for word in Luther's writings, see for instance his preface to the psalms, Psalterium Translationis veteris, Correctum (Wittenberg, 1529), sig. A ij, r-A, vij, r.

35 Philipp Melanchthon, in his primer Elementa puerilia, quoted in Gerald Strauss, Luther's House of Learning. Indoctrination of the Young in the German Reformation (Baltimore: Johns Hopkins University Press, 1978), 189.

36 I know of no modern study on primers in Northern Europe around 1500, but I am much indebted to Strauss' short account of the Protestant Reformation and literacy in Luther's House of Learning, 194-202.

37 The German titles can be found in Strauss, Luther's House of Learning, 360, n. 126. Strauss' translations.

38 Quoted in Strauss, Luther's House of Learning, 195. Strauss' translation.

39 Quoted in ibid., 196. Strauss' translation.

40 Quoted in ibid., Strauss' translation.

41 Quoted in ibid., p. 196-7. Strauss' translation.

42 Quoted in ibid., p. 197. Strauss' translation.

43 Ibid.

44 Ibid., 198-9.

45 Martin Luther, De servo arbitrio, WA 18 (= D. Martin Luthers Werke, kritische Gesamtausgabe, Weimar 1883-), 687: "[Rideat me quispiam tam] crasse disputantem [ac velut] analphabetis puerilis praemansum tantis viris porrigentem ac syllabas nectendas docentem." Thus, using a simile to describe his harsh and critical attitude towards Erasmus, the practice of the syllabic method is displayed by Luther as everything but attractive.

46 Hence, provided that the pupil was not rushed but was allowed to progress slowly, it took a six-year-old child one or, more likely, two years to learn to read under this system, see Strauss, Luther's House of Learning, 199.

47 An Italian do-it-yourself primer of 1524 emphasizes that the school route to literacy "would involve a great loss of time, not merely by days and months, but even years." See Anne Jacobson Schutte, "Teaching Adults to Read in Sixteenth-Century Venice: Giovanni Antonio Tagliente's Libro Maistrevole," Sixteenth Century Journal 17 (1986): 3-16, 11.

48 See Michael Giesecke, "Alphabetisierung als Kulturrevolution. Leben und Werk Valentin Ickelsamers," in Sinnenwandel, Sprachwandel, Kulturwandel. Studien zur Vorgeschichte der Informationsgesellschaft (Frankfurt am Main: Suhrkamp, 1992), 122-185; Strauss, Luther's House of Learning, 195-7.

49 Ickelsamer, Ein Teutsche Grammatica (1534), quoted in Strauss, Luther's House of Learning, 195. Strauss' translation.

50 Ibid.

51 See Giesecke, "Alphabetisierung als Kulturrevolution," 134.

52 Ibid., 143-151.

53 Comenius, Pampadia: lateinische Text und deutsche Übersetzung, Dmitrij Tschizewskij, ed. (Heidelberg: Quelle \& Meyer, 1960), 258: "Etiam Infantes Verba doceamus ductu Rerum, hoc est sapere utique loqui [...] commonstrando rem, dictat: Quid hoc est? rursumque rem nominando, ostendi sibi jubeant: Ubi est Canis? Ubi est Mensa? Ubi Caput tuum?" 
54 Ibid., 262: "Similiter Lingua nonnisi à lallando incipit, perque balbutiem ad loquelam progrediatur, duce semper autopsia et authapsia. Abstractè enim de rebus loqui eis non possumus, qui nondum notiones à rebus abstraxerunt, mentique suae impresserunt, ut auditâ voce notionem ejus moveri, sentire possint. Difficilè ergò est infantibus loqui; facilè res ipsas offerre, monstrare, demumque nominare. Sive: Quia ergò non illis nondum loqui possumus, loquatur ipsa natura, illorum se oculis, auribus, naribus, palato, manibusque imprimendo."

55 Daniel Murphy, Comenius. A Critical Reassessment of his Life and Works (Dublin: Irish Academic Press, 1995), 183.

56 Comenius, Pampedia, 276: "Lucidarium, continens res obvias, domesticas - et inscriptionem; ante omnia verò Alphabetum vivum."

57 Comenius, Orbis sensualium pictus, trans. Charles Hoole (London, 1659), 3.

58 Comenius, Didactica magna, in Joannes Amos Comenius, Opera Didactica Omnia, vol. 1 (Prague: Academia Scientiarum Bohemoslovenica, 1957), 188: "Ita qvæ pueris muti eorum magistri, Libelli, offerunt, revera muta, obscura, imperfecta sunt."

59 Comenius, Pampædia, 274: "Magnis ... molestiis juventuti constat literas discere nosse et pingere. Opere ergò pretium fuerit primas istas eruditionis radices amaras arte aliquâ edulcare, ut molestiam non sentiant. Hoc autem aliter non potest, quàm si severior ille labor in formam lusionis commutari possit."

60 Comenius, Orbis sensualium pictus, preface.

61 Ibid.

62 Comenius, Pampaedia, see note 54 above.

63 Erasmus, Paraclesis, see note 23 above.

64 Jesper Swedberg, Mindre Scholelek (Skara, 1708), preface: "Herrans röst sitter mig i öronen/ och städer mig stundom intet sova. Hon steller sig undertiden in/ mitt i min bästa ro med mina förtroligaste wänner/ och hwiskar mig uti öronen/ så att hiärtat rörs och pusten hörs."

65 See Richard Gawthrop and Gerald Strauss, "Protestantism and Literacy in Early Modern Germany," Past \& Present 104 (1984): 31-55; Richard L. Gawthrop, "Literacy

Campaigns in Pre-Industrial Germany," National Literacy Campaigns, 29-48.

66 Johansson, "The History of Literacy in Sweden," 151-182.

67 On the ritualized violence of early modern schooling, see Walter J. Ong, "Latin Language Study as a Renaissance Puberty Rite," Studies in Philology 56 (1959), 103-24.

68 Johannes Gezelius, Methodus informandi in pedagogiis tam ruralibus quam urbicis (Åbo, 1683), I, \$ 11: "Pædagogus måste ock ... wara nychter/ och underwijsa Barnen medh beskedeligheet/ mehra med Liufligheet än medh hotande och straff komma dem att lära; elliest elska de intet Boken/ utan blifwa ledze wid henne/ och önska slippa ifrån lärandet.”

69 Hilding Pleijel, ed., Herman Schröders Levernesbeskrivning (Stockholm: Svenska Kyrkans diakonistyrelse, 1940), 26: "Såsom pilten må tuchtas med rijs för odygds feel, at skalcken i tider må dämpas, så måste man theremot hwad lectioner och wetenskaper angår, ej med hårdhet, grym upsyn samt hugg och slag söckja thet i barnet intrycka, ty theraf fattas mehra leda och olust til at lära något än lust och kiärlek, utan hwilcken man föga skickelig blifwer til at lära något."

70 Jesper Swedberg, Mindre Scholelek, \$. 3.

71 Ibid.: "Moste intet mera leggia them uppå/ än the förmå at draga. Och thet utan twång/ utan trug/ utan slag; alt med foglighet/ lempo/ lust och lek."

72 Josef Helander, ed., Biskop A. O. Rhyzelii antecknigar om sitt lefverne (Uppsala: Skrifter utgifna af kyrkohistoriska föreningen, 1901), 4: “Vnder mitt siukliga tillstånd war ock thet nog bewis til minne och qwickhet, at jag på kort tid lärde af min s. moder icke allenast läsa i bok, vtan ock at siunga psalmer, läsa böner och en del av catechesi, innan min s. fader weste theraf, som såg mig nästan altid sengliggande. Therföre wälsignade han min k. moder, gladdes hierteligen och gaf mig en bok, som kallas Orbis Pictus, til att roa 
mig med. Och thetta skedde år 1685, tå biskop Spegel kom til Skara . . År 1686 war jag åter siuk hela wintern och wåren, men Orbis Pictus altid i sengen hos mig. Jag lärde läsa honom vtan til, fast jag icke förstod en enda rad."

73 Rhyzelius was appointed as a professor of theology in 1711 and made bishop in 1743.

74 On Gezélius and Comenius, see Markku Leinonen, "Johannes Gezélius den äldre (16151690) och utgivningen av Orbis Pictus på svenska," in Johan Amos Comenius, Orbis Sensualium Pictus, ed. Lars Lindström (Stockholm, HLS Förlag, 2006), 368-391.

75 On Gezélius and the Church Law, see Arnold Sandberg, Linköpings stifts kyrkoarkivalier intill år 1800. En arkivhistorisk undersökning (Linköping: Sahlström, 1948), 167-8.

76 Source material is scant, since primers were seldom stored in Swedish archives around 1700. From the mid-eighteenth century, however, there is evidence of widespread use of Orbis pictus, see Ingeborg Willke, $A B C$-Bücher in Schweden: ihre Entwicklung bis ende des 19. Jahrhunderts und ihre Beziehungen zu Deutschland (Stockholm: Svenska Bokförlaget, 1965), 17, 67.

77 Comenius, Informatorium maternum eller Moder-Schola, transl. Erik Schroderus (Stockholm, 1642), reprint in Årsböcker för svensk undervisningshistoria 33 (1932): 17-18: "Ludi literarij"; "Bookstäfwers lek [...] Medh hwilke sidste Ord beteknas/ at Ungdomens Öfning är både them som lära och läras uthi sigh sielf liufligh/ behagelig/ och icke annat än såsom en Leek eller Tijdsfördreef."

78 Gunnar Wetterberg, ed., Jesper Swedbergs Lefwernes Beskrifning, in Skrifter utgivna av vetenskaps-societeten i Lund 25:1 (1941), 113: "Hafwer nu ock begynt ett sådant sett at lära them sina christendoms stycken, at hwar affton effter måltiden skola barnen och legofolcket taga zedlar, på en dehl står läser, på en thel intet. Then som får läser skal läsa ett stycke af Catechesen: thet jag ock sedan för them förklarar med förmaning, at lefwa ther effter. Och lärer således, och styrcker mig och them i trones kundskap och sann gudachtighets öfning."

79 See Kyrkio-Lag och Ordning, 2, \$. 10.

80 Jesper Swedbergs Lefwernes Beskrifning, 390: "Men med Catechismi gudeliga och vpbyggeliga förhör icke så.”

81 Foucault's major argument on disciplinary power is found in Discipline and Punish: The Birth of the Prison, transl. Alan Sheridan (London: Allen Lane, 1977), 135-228.

82 Ibid., 170.

83 Ibid. Foucault's argument is on a universal level; he does not mention alphabetization.

84 Cf. Foucualt, "The Subject and Power," in Essential Works of Foucault, 1954-1984, ed. James D. Faubion, vol. 3, Power (New York: The New Press, 2000), 331.

85 Jesper Swedbergs lefwernesbeskrifning, 122, 123: "på thet fogligaste och lindrigaste"; "[s]å måste man vmgås med sina åhörare, och ingalunda bry och plåga them med torra och magra frågor och spörsmåhl."

86 Ibid., 123: "Si, så moste man komma ryttaren och soldaten; intet med hot och trug, intet med spö och påla, at läsa."

87 Ibid., 124: "Konungen frågar mig, wid Hans Majestet gaf mig Docaterna; om the alle äro så flitige och willige til at läsa? Nu hade jag ifrå then tiden jag först kom til regementet vpteknat allas läsning och lefwerne. Jag fick en stor hop, som woro genstörtige och genstrefwige, hollande sig vndan från förhöret, och them som förde ett liderligit lefwerne. Vptekningen tog Konungen af mig, och befalte Öfwerstan Fägerschöld at alle skulle slås på pålan. Tå blef thet alarm vtaf $\mathrm{i}$ lägret. Och så monge pålar woro intet til fångs $\mathrm{i}$ hastighet. Jag lindrade straffet; at the som motwilligaste, wahnartigaste och försumeligaste woro, vpgofwos. Och Pålaksbacken blef vtstofferad med en hop pålare och en ryttare wid hwar och en påla. Efter then tiden blefwo the lydige och frome. Vexatio dat intellectum lyder ordspråket."

88 Foucault, Discipline and Punish, 189-91.

89 Ibid., 189, 192. 
90 See Kyrkio-Lag och Ordning, chap. 2, §. 10: "Presterna skola hålle wisse lengder på alle sine åhörare, Huus ifrån Huus, Gård ifrån gård, och weta besked om theras framsteg och kunskap."

91 On the dyslexia of Charles XI, see Arne Losman, "Tre karlars studier," in Tre Karlar: Karl X Gustav, Karl XI, Karl XII (Stockholm: Livrustkammaren, 1984), p. 18-19.

92 Sten Lindroth, Svensk lärdomshitoria: Stormaktstiden, vol. 2 (Stockholm: Norstedts, 1975), 88.

93 See A Revolution from Above. The Power State of the 16th and 17th Century Scandinavia, ed. Leon Jespersen (Odense: Odense University Press, 2000).

94 For Sweden's experience of empire, see the various essays in Michael Roberts, ed., Sweden's Age of Greatness, 1632-1718 (London: Macmillan, 1973).

95 See Jan Lindegren, “The Swedish Military State, 1560-1720," Scandinavian Journal of History 10 (1985): 305-336.

96 On the spread of "social discipline" in seventeenth-century Sweden, see, for instance, Stellan Dahlgren, "Karl XI:s envälde — kameralistisk absolutism?," in Stellan Dahlgren, ed., Makt och vardag: Hur man styrde, levde och tänkte under svensk stormaktstid (Stockholm: Atlantis, 1993), 115-132.

97 Foucault, "The Subject and Power," 332. While actually refering to "pastoral power," Foucault's argument holds true for discipline as well.

98 Foucault, "The Subject and Power," 334.

99 See Wolfgang Reinhard, "Humanismus und Militarismus. Antike-Rezeption und Kriegshantwerk in der oranische Heeresreform," in Franz Josef Worstbrock, ed., Krieg und Frieden im Horizont der Renaissancehumanismus (Wernheim: Wiley-VCH, 1986), 185-204.

100 John of Nassau, quoted in Gerhard Oestreich, "Der römische Stoizismus und die oranische Heeresreform," in Oestreich, Geist und Gestalt des frühmodernen Staates (Berlin: Duncker \& Humblot, 1969), 11-34, quotation on page 26.

101 See Michael Roberts, “The Military Revolution, 1560-1660," in Essays in Swedish History (London: Weidenfeld \& Nicolson, 1967), 195-225.

102 Quoted in Sveriges Krig VII (Stockholm: Generalstaben, 1936), 99-100.

103 Gustavus Adolphus' discipline was noted by Foucault, Discipline and Punish, 150.

104 See Barbara Donagan, "Halcyon Days and the Literature of War: England's Military Education Before 1642," Past \& Present 147 (1995): 65-100, quotation on page 85.

105 On the military dream of society, see Foucault, Discipline and punish, 168-9.

106 Robert Monro, Monro, His Expedition with the Worthy Scots Regiment Called Mac-Keys (London, 1637), 195.

107 The Oxford Encyclopedia of the Reformation, vol. 2 (Oxford: Oxford University Press, 1996), 429. 
82 Historical Studies in Education/Revue d'histoire de l'éducation 